\title{
Uloga Laboratorija za tipizaciju tkiva u povijesnom razvoju transplantacije bubrega u Rijeci
}

\section{The role of tissue typing Laboratory in the Historical Development of the Kidney Transplantation in Rijeka}

\author{
Nataša Katalinić ${ }^{1,2^{*}}$, Sanja Balen ${ }^{1,2}$
}

${ }^{1}$ Klinički zavod za transfuzijsku medicinu, KBC Rijeka

${ }^{2}$ Medicinski fakultet Sveučilišta u Rijeci

\section{"Dopisni autor:}

Dr. sc. Nataša Katalinić, dr. med.

Laboratorij za tipizaciju tkiva,

Klinički zavod za transfuzijsku medicinu, KBC Rijeka, Tome Strižića 3, 51000 Rijeka e-mail: tipizacija@kbc-rijeka.hr

http://hrcak.srce.hr/medicina
Sažetak. Prva uspješna transplantacija bubrega u Jugoslaviji ostvarena je u Rijeci 30. siječnja 1971. kao rezultat multidisciplinarne suradnje u kojoj su značajni doprinos pružili djelatnici Laboratorija za tipizaciju tkiva, tada bolnice "Dr. Zdravko Kučić" na Sušaku, a danas Kliničkog bolničkog centra $(\mathrm{KBC})$ u Rijeci. Upravo su intenzivne pripreme za zahvat transplantacije potakle osnivanje prvog Laboratorija za tipizaciju tkiva u Hrvatskoj pri Stanici, kasnije Zavodu za transfuzijsku medicinu. Ovim radom prikazan je utjecaj povijesnog razvoja Laboratorija na uspješnost transplantacijskog programa te postizanje i održavanje statusa riječkog KBC-a kao jednog od vodećih transplantacijskih centara u Hrvatskoj. Temeljem proučavanja povijesnih dokumenata Laboratorija i arhive KBC-a prikazan je razvoj tipizacije tkiva u Rijeci od osnutka Laboratorija 1971. do danas. Opisan je napredak u usvajanju novih metoda tipizacije tkiva u određivanju polimorfizma sustava HLA, probiru seruma pacijenata na prisustvo protutijela HLA i određivanju njihove specifičnosti, te križnih proba u svrhu otkrivanja donor-specifičnih protutijela. Odabir i primjena optimalnih metoda rada u Laboratoriju pridonijela je usvajanju najnovijih spoznaja u transplantacijskoj imunologiji i povijesnom razvoju transplantacijskog programa u Rijeci.

Ključne riječi: povijest; Rijeka; sustav HLA; testovi tkivne podudarnosti; transplantacija bubrega; transplantacijska imunologija

Abstract. The first successful kidney transplantation in Yugoslavia was performed in Rijeka, on the $30^{\text {th }}$ of January, 1971, at that time in the "Dr. Zdravko Kučić" Hospital at Sušak, and today in the Clinical Hospital Centre (CHC) in Rijeka. The transplantation was a result of a multidisciplinary cooperation where a significant contribution was provided by the Tissue Typing Laboratory employees. Intensive preparations for the transplant procedure have been crucial for the founding of the first Tissue Typing Laboratory in Croatia as a part of the Station, later the Transfusion Medicine Institute. This paper presents the impact of the historical development of the Laboratory on the success of the transplant programme, the achievement and maintenance of the status of the CHC Rijeka, as one of the leading transplant centre in Croatia. Based on the study of the historical documents of the Laboratory and $\mathrm{CHC}$ archives, the development of tissue typing in Rijeka has been presented here since the establishment of the Laboratory in 1971 until the present day. The progress has been described in the adoption of new tissue typing methods in determining the polymorphism of the HLA system, the serum screening for the presence of HLA antibodies and determination of their specificity, as well as crossmatches for detecting donor-specific antibodies. Selection and application of optimal work methods at the Tissue Typing Laboratory contributed to the adoption of the latest findings in transplant immunology and the historical development of the transplant programme in Rijeka.

Key words: history; HLA antigens; kidney transplantation; Rijeka; tissue compatibility analysis; transplantation immunology 


\section{UVOD}

Hrvatska je danas jedna od vodećih zemalja u svijetu u području darivanja i presađivanja organa ${ }^{1}$. Začetci ovog značajnog uspjeha hrvatske transplantacijske medicine vezani su uz Rijeku. U Općoj bolnici Dr. Zdravko Kučić na Sušaku, pod vodstvom prof. dr. sc. Vinka Frančiškovića, izvedena je prva uspješna transplantacija bubrega na području Jugoslavije 30. siječnja 1971. godine ${ }^{2}$. Transplantacija je bila rezultat temeljitih, višegodišnjih priprema i multidisciplinarne suradnje stručnjaka interne medicine, kirurgije, anesteziologije, imunologije, transfuzijske medicine, tipizacije tkiva i ostalih vezanih područja medicine $i$ temeljnih medicinskih znanosti.

Pripreme za transplantaciju bubrega u Rijeci bile su poticaj osnivanju prvog Laboratorija za tipizaciju tkiva u Republici Hrvatskoj u siječnju 1971. godi$n^{3}$. Do tada je u Jugoslaviji djelovao jedino Centar za tipizaciju tkiva u Ljubljani, osnovan dvije godine prije, pod vodstvom profesorice Mateje Bohinjec. $\mathrm{Na}$ čelu Laboratorija u Rijeci, koji je u početku bio dio Stanice za transfuziju krvi, a kasnije Zavoda za transfuziologiju Kliničkoga bolničkog centra Rijeka, bila je profesorica Ksenija Vujaklija-Stipanović do odlaska u mirovinu 2004. Tada stručno vodstvo Zavoda i Laboratorija nastavlja prof. dr. sc. Sanja Balen koja je 2008. uspostavila Klinički zavod za transfuzijsku medicinu KBC-a Rijeka ${ }^{4}$.

Razvojni put Laboratorija obilježilo je praćenje najnovijih spoznaja u području transplantacijske imunologije te uspješna suradnja s mnogim stručnjacima vrhunskih medicinskih središta poput Bostona, Lyona, Aarhusa, Ljubljane i ostalih. Od 1985. Laboratorij aktivno sudjeluje u radu Collaborative Transplant Study (CTS), velike studije kojom je profesor Gerhard Opelz u Heidelbergu (Njemačka) povezao iskustva više stotina transplantacijskih centara u svrhu istraživanja i stjecanja novih znanja u transplantacijskoj imunologiji ${ }^{5,6}$.

Godine 2007. Hrvatska je postala punopravna članica Eurotransplanta, međunarodne organizacije koja koordinira dodjelu organa između Belgije, Njemačke, Luksemburga, Nizozemske, Madžarske, Austrije i Slovenije ${ }^{7}$. Da bi i Rijeka mogla ravnopravno sudjelovati u europskom transplantacijskom programu kojem se već pridružio Zavod za tipizaciju tkiva Klinike za urologiju KBC-a Zagreb, pred Laboratorij za tipizaciju tkiva postavljen je velik izazov. Naime, tijekom posljednjih desetljeća u Laboratorij se malo ulagalo te nije zadovoljavao prostorne, tehnološke, kadrovske niti stručne zahtjeve. Prema sjećanju profesorice Balen „„... tada je to izgledalo kao 'nemoguća misija' jer postojeći Laboratorij uslijed višegodišnjeg neulaganja i nedostatnih financijskih sredstava nije bio niti blizu potrebnim standardima. Međutim, nije bilo lako donijeti odluku o ukidanju prvog osnovanog Laboratorija za tipizaciju u Republici Hrvatskoj..."

Hrvatska je danas jedna od vodećih zemalja u svijetu u području darivanja i presađivanja organa. Začetci ovog značajnog uspjeha hrvatske transplantacijske medicine vezani su uz Rijeku gdje je izvedena prva uspješna transplantacija bubrega na području Jugoslavije te osnovan prvi Laboratorij za tipizaciju tkiva u Hrvatskoj u siječnju 1971.

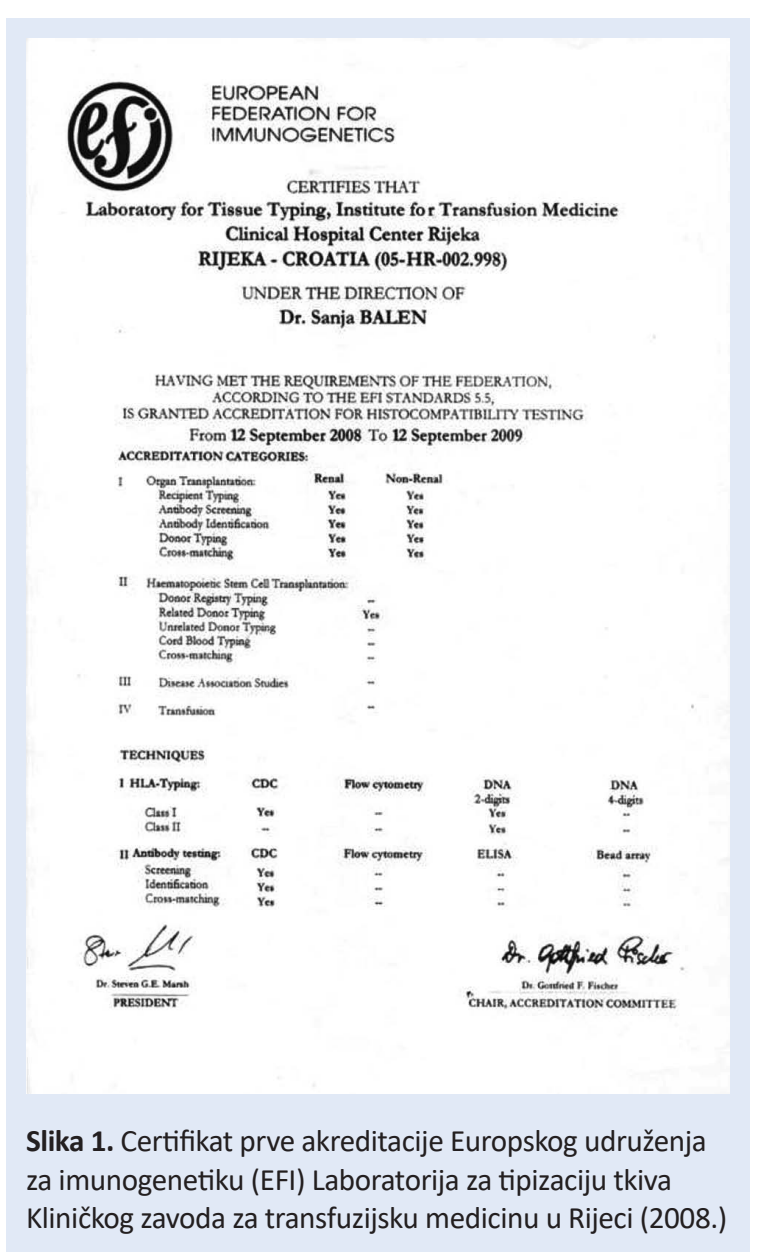


Zahvaljujući naporima i velikom entuzijazmu svih djelatnika, Laboratorij je prostorno proširen, opremljen novom opremom i aparaturom, uvedene su nove metode testiranja, povećan je broj djelatnika, omogućena je edukacija, značajno je podignuta razina sustava kontrole kvalitete. Nekoliko europskih eminentnih stručnjaka u području imunogenetike posjetilo je Laboratorij i prije rujna 2008., kada je prvom službenom inspekcijom stekao akreditaciju European Federation for Immunogenetics (EFI) (slika 1). Redovito obnavljanje akreditacije omogućuje aktivnu, sada već i desetogodišnju, suradnju riječkog Centra s Eurotransplantom.

Upravo je aktivno sudjelovanje Laboratorija već tijekom priprema za prve transplantacije bubrega omogućilo stvaranje preduvjeta da se od samih početaka usvoje neki od imunoloških testova. To su bili: podudarnost u ABO sustavu krvnih grupa, što bolja podudarnost u sustavu HLA te negativna križna reakcija između seruma primatelja i limfocita davatelja ${ }^{8,9}$. Ovi kriteriji poštuju se i danas.

\section{TIPIZACIJA SUSTAVA HLA}

Tijekom transplantacije bubrega unosi se velika količina primatelju više ili manje stranih molekula. Temeljem važnosti antigenskih determinanti u pokretanju imunosne reakcije odbacivanja transplantiranog bubrega, (ne) podudarnost u lokusima razreda I (HLA-A,-B) i razreda II (HLA-DR) između primatelja i davatelja predstavljaju jedan od najznačajnijih imunosnih čimbenika koji utječu na ishod transplantacije bubrega ${ }^{10,11}$. Stoga je važno odrediti polimorfizam molekula HLA primatelja i davatelja te težiti čim boljoj podudarnosti, što je omogućeno i razvojem tehnika tipizacije ${ }^{12}$.

Početke tipizacije tkiva u svijetu, sredinom 60-ih godina prošloga stoljeća, označile su stanične i serološke metode, poput miješane kulture limfocita (engl. Mixed Lymphocyte Culture; MLC) i testa limfocitotoksičnosti ovisne o komplementu (engl. Complement-Dependent Cytotoxicity; CDC). Nakon nekoliko prvih tipizacija tkiva pacijenata liječenih u Centru za dijalizu Rijeka učinjenih u Lyonu (Francuska) i Los Angelesu (SAD) u Laboratoriju za tipizaciju tkiva u Rijeci započelo je određivanje polimorfizma antigena HLA razreda I metodom CDC (slika 2).
Sedamdesetih godina prošlog stoljeća ploče za tipizaciju sustava HLA stvarane su od seruma humanog podrijetla - imuniziranih pacijenata $\mathrm{i}$ višerotki (slika 3). Uzorci seruma testirali su se na prisutnost protutijela HLA u različitim koncentracijama, te se određivala specifičnost i titar.

Kako je malo laboratorija u to vrijeme moglo sastaviti ploču oslanjajući se na vlastite izvore, stvaranje vlastitih in house ploča bilo je omogućeno uskom suradnjom riječkog Laboratorija i Centra za tipizaciju tkiva Ljubljana. Time je ostvaren jedan od važnih preduvjeta za tipizaciju umrlog davatelja i prvu kadaveričnu transplantaciju bubrega u KBC-u Rijeka (slika 4). Nekoliko godina je Referalni centar za tipizaciju tkiva Jugotransplanta u Zagrebu preuzeo formiranje i razdiobu ploča za tipizaciju ${ }^{13}$. Međutim, gašenjem Jugotransplanta centri za tipizaciju ponovno su se počeli oslanjati na vlastite izvore. Različitosti u kvaliteti seruma i njihove kombinacije na pločama uzrokovale su naglašenu razliku kvalitete tipizacije, ne samo između centara već i između različitih serija ploča. Stoga se u svijetu, a tako i kod nas, stremilo standardizaciji reagensa. Nakon

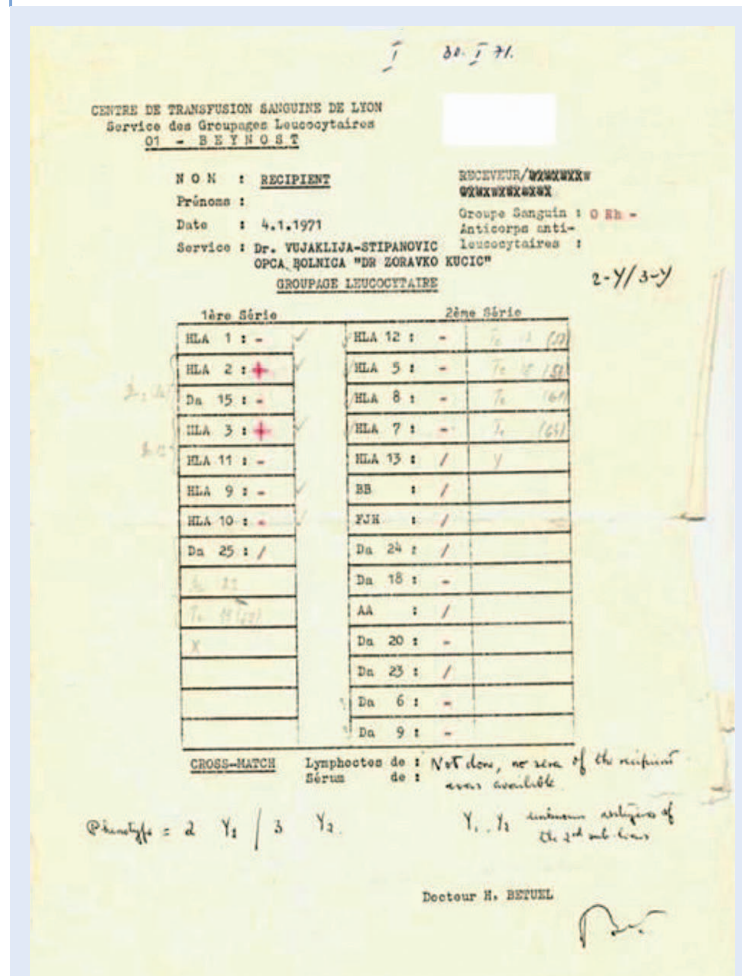

Slika 2. Nalaz tipizacije HLA prvog pacijenta transplantiranog u Rijeci (Centre de transfusion sanguine de Lyon, Francuska, 1971.) 


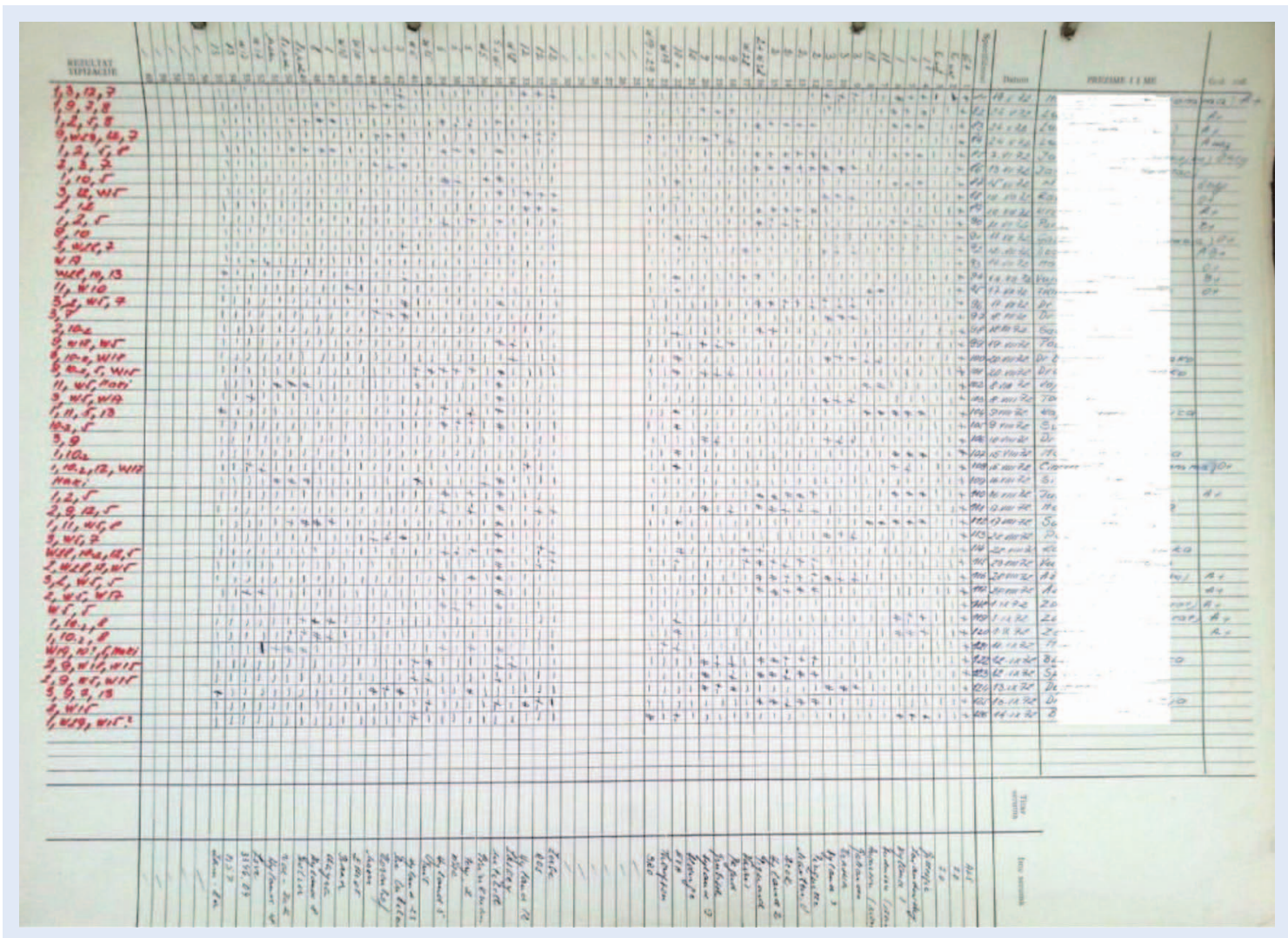

Slika 3. Probir seruma trudnica i rodilja prije otpusta iz bolnice na prisutnost protutijela HLA (1992.)

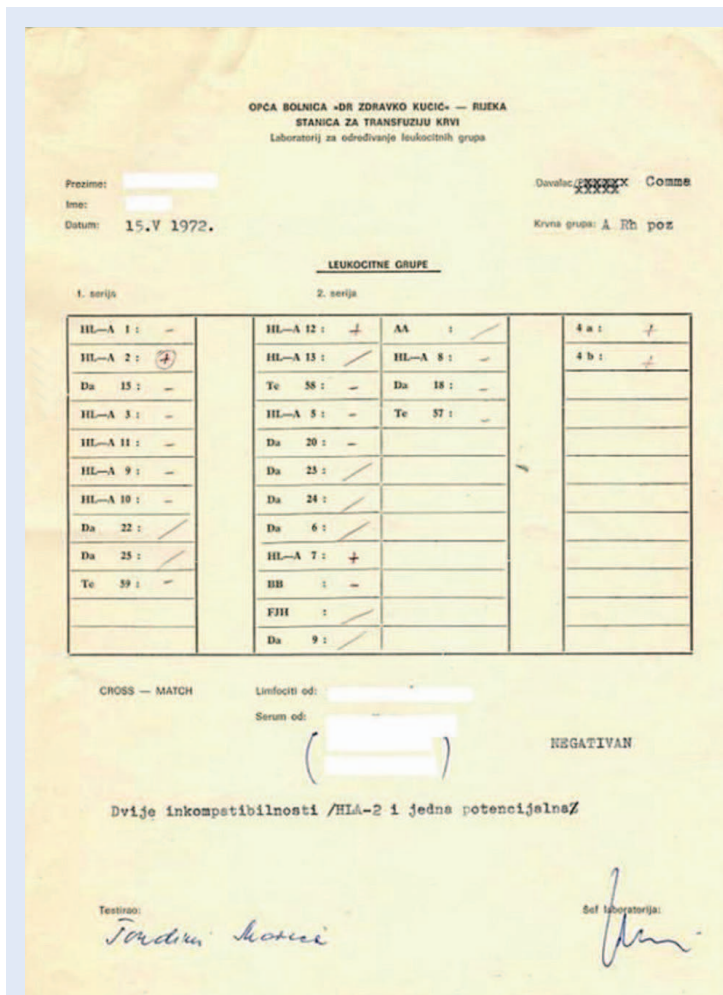

Slika 4. Nalaz tipizacije HLA prvog umrlog davatelja bubrega u Rijeci (1972.) dugogodišnje upotrebe in house ploča u riječkom Laboratoriju za tipizaciju tkiva, danas se serološka tipizacija antigena HLA izvodi na pločama komercijalnih proizvođača ${ }^{12}$.

Serološka tipizacija lokusa HLA razreda II donijela je znatan napredak u transplantacijskoj imunologiji. U Hrvatskoj je tipizacija antigena lokusa HLA-DR započela u Zavodu za tipizaciju tkiva KBC-a Zagreb krajem sedamdesetih, a u Rijeci od 1985. godine $^{12,14}$. Od 1993. testiranje se proširilo i na određivanje polimorfizma antigena HLA-DQ.

Značajnu prekretnicu donijelo je otkriće metoda molekularne biologije i razvoj tehnika tipizacije gena HLA, 80-ih godina prošlog stoljeća. Jedna od najprihvaćenijih i najčešće primjenjivanih metoda u laboratorijima za tipizaciju tkiva je lančana reakcija polimerazom i početnicama specifičnih za alel ili skupinu alela (engl. Single Specific PrimerPolymerase Chain Reaction; PCR-SSP). Određivanje alela HLA metodom PCR-SSP započelo je 1990. u Centru za tipizaciju tkiva KBC-a Zagreb s kojim je riječki Laboratorij uspostavio suradnju u prosincu 2001. Time je pokrenuta tipizacija lokusa HLA-DR na molekularnoj razini u pacijenata na 
Listi čekanja riječkog Centra. Metoda PCR-SSP uvedena je u Rijeci 2005. u tipizaciji alela HLA razreda II, a nakon dvije godine i razreda I. Od ožujka 2015., uz navedene metode, serološku i PCR-SSP, uvedena je tipizacija alela HLA metodom lančane reakcije polimerazom i oligonukleotidima specifičnih sekvenci (engl. Polymerase Chain Reaction - Sequence Specific Oligonucleotids; PCR-SSO) najsuvremenijom Luminex-citometrijom $^{12}$.

Laboratorij za tipizaciju tkiva Kliničkog bolničkog centra u Rijeci stekao je akreditaciju Europske federacije za imunogenetiku (EFI), najvećeg europskog udruženja imunogenetičara, 2008. godine. Time je postao jedan od dva hrvatska laboratorija koji su ispunili uvjet za aktivno sudjelovanje i rad u sustavu Eurotransplanta, međunarodne organizacije za dodjelu i razmjenu organa.

ISPITIVANJE PRISUTNOSTI I ODREDIVANJE SPECIFIČNOSTI PROTUTIJELA HLA U SERUMU PACIJENATA

Protutijela HLA stvaraju se kao reakcija na izloženost primatelja tuđim antigenima HLA tijekom prethodnih transplantacija organa ili tkiva, trudnoća i/ili transfuzija krvnih pripravaka ${ }^{15}$. U transplantaciji organa prisutnost protutijela HLA koja su usmjerena prema antigenima izraženima na presatku može dovesti do akutne (hiperakutne) i kronične reakcije odbacivanja ${ }^{16,17}$. Zbog toga je određivanje prisutnosti i specifičnosti protutijela HLA u potencijalnog primatelja organa (engl. screening) najveći imunogenetski izazov svakog laboratorija za tipizaciju tkiva.

Metoda CDC, poznata više od pedeset godina, i danas predstavlja zlatni standard u otkrivanju protutijela HLA. U riječkom Laboratoriju screening protutijela počeo se provoditi metodom CDC gotovo od samih početaka rada. $U$ tu svrhu formiran je prvi panel limfocita u Republici Hrvatskoj 1972. godine zahvaljujući pomoći profesora Flemminga Kissmeyer-Nielsena, osnivača Scandiatransplanta. Četrdeset uzoraka krvi zdravstvenih djelatnika Stanice za transfuziju krvi te članova transplantacijskog tima sušačke bolnice tipizirano je tijekom listopada i studenoga 1972. u Tissue
Typing Laboratory, Aarhus Kommunehospital, Aarhus (Danska) ${ }^{3}$. Testiranje davatelja limfocita panela nastavilo se u Laboratoriju za tipizaciju tkiva u Rijeci (slika 5).

Screening se izvodio sa svježe izoliranim limfocitima, što je određivalo, ali i ograničavalo, sastav i broj limfocita panela (slika 6). Zamrzavanje limfocita, a naročito uvođenje tehnike zamrzavanja u tekućem dušiku 1985., omogućilo je stvaranje dosljednog panela odgovarajućeg sastava i broja limfocitnih antigena tako da predstavlja odraz učestalosti alela ispitivane populacije stanovništva.

$U$ početku, imunizirani pacijenti testirali su se svakih mjesec dana, a neimunizirani pri prvom dolasku u Laboratorij te ponovno samo nakon transfuzije krvi. Ispitivani uzorci seruma su se zamrzavali i koristili u izvođenju križne probe prije transplantacije bubrega ${ }^{8}$. Prateći suvremene spoznaje transplantacijske imunologije, poslije je uveden probir seruma periodično, svaka tri mjeseca, što se provodi i danas.

U svrhu povećanja osjetljivosti uvedeno je nekoliko modifikacija u screening metodu CDC-a. Krajem 70-ih produžilo se vrijeme inkubacije, a takozvani kratki i dugi screening izvodio se gotovo deset godina. Od 2008. screening seruma pacijenata na prisustvo HLA izvodi se bez i s dodatkom dithiothreitola (DTT) kako bi se razlučio razred ( IgG, IgM) prisutnih protutijela HLA.

Nedovoljna osjetljivost CDC testa potaknula je razvoj metoda koje mogu otkriti prisutnost protutijela HLA u niskom titru, poput staničnih tehnika (protočna citometrija) i tehnika čvrste faze (ELISA, Luminex) ${ }^{18-21}$. Tako je u Rijeci, uz CDC tehniku, od 2012. uveden probir seruma pacijenata najosjetljivijom tehnikom Luminex-citometrije, što je omogućilo praćenje najsuvremenijih spoznaja o humoralnom odbacivanju presatka. Početkom 2016. uvedeno je sustavno praćenje imunosnog statusa pacijenata i nakon transplantacije bubrega primjenom metoda CDC i Luminex.

Do početka 2018. u Laboratoriju za tipizaciju tkiva u Rijeci učinjen je screening seruma u više od 3000 pacijenata kao dio obrade za prijavu na Listu čekanja.

Valja napomenuti da je Laboratorij u Rijeci od početka bio dio transfuzijskog centra, te su pomno praćene spoznaje o ulozi transfuzija krvi na stvara- 
nje protutijela HLA i utjecaju na transplantaciju bubrega. Duga tradicija restriktivne politike transfuzijskog liječenja potencijalnih primatelja bubrega jedan je od razloga značajno manjeg udjela imuniziranih pacijenata u riječkom Centru u odnosu na druge ustanove u Hrvatskoj i svijetu'12,22.

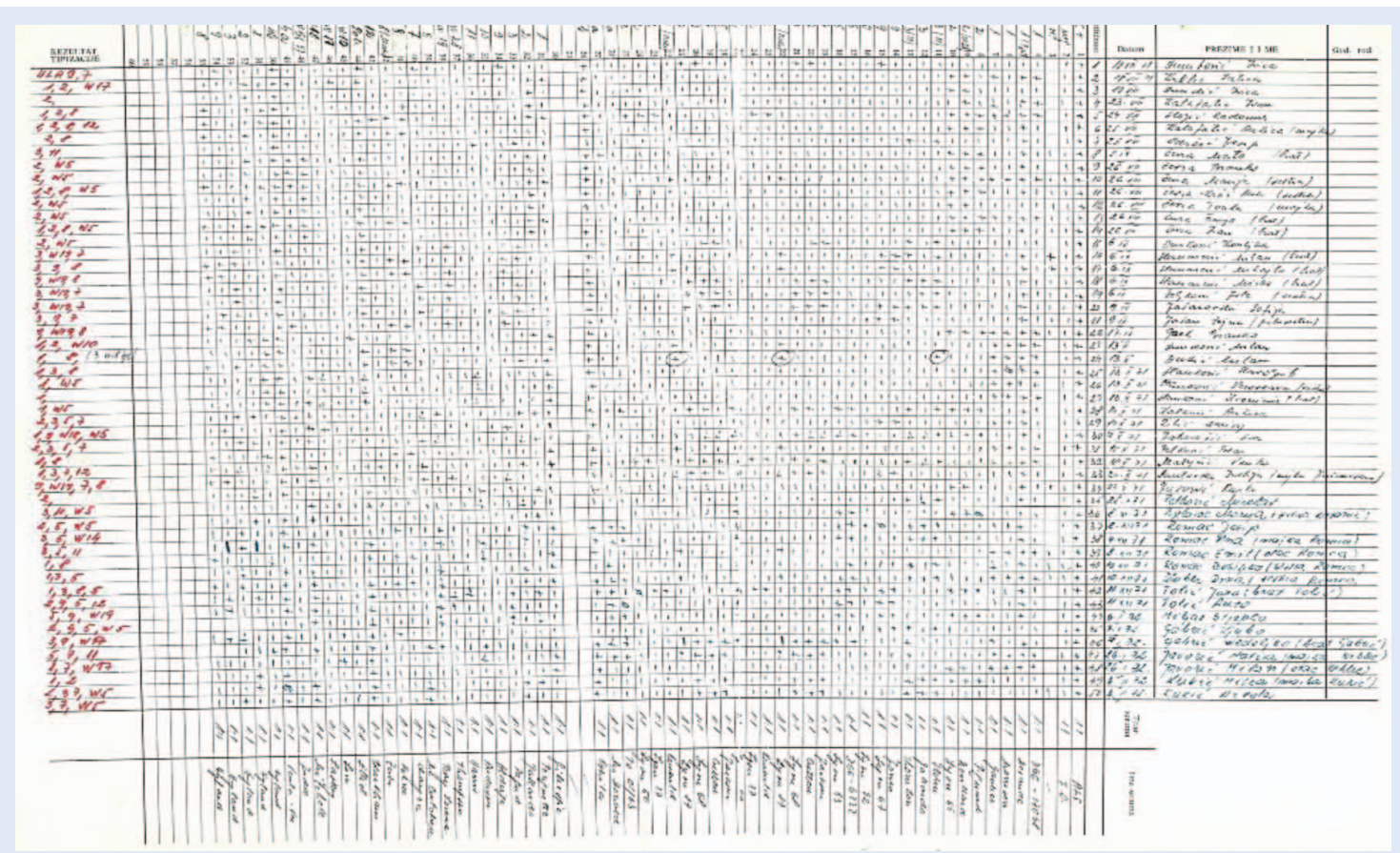

Slika 5. Rezultati testiranja davatelja limfocita prvog panela u Laboratoriju za tipizaciju tkiva

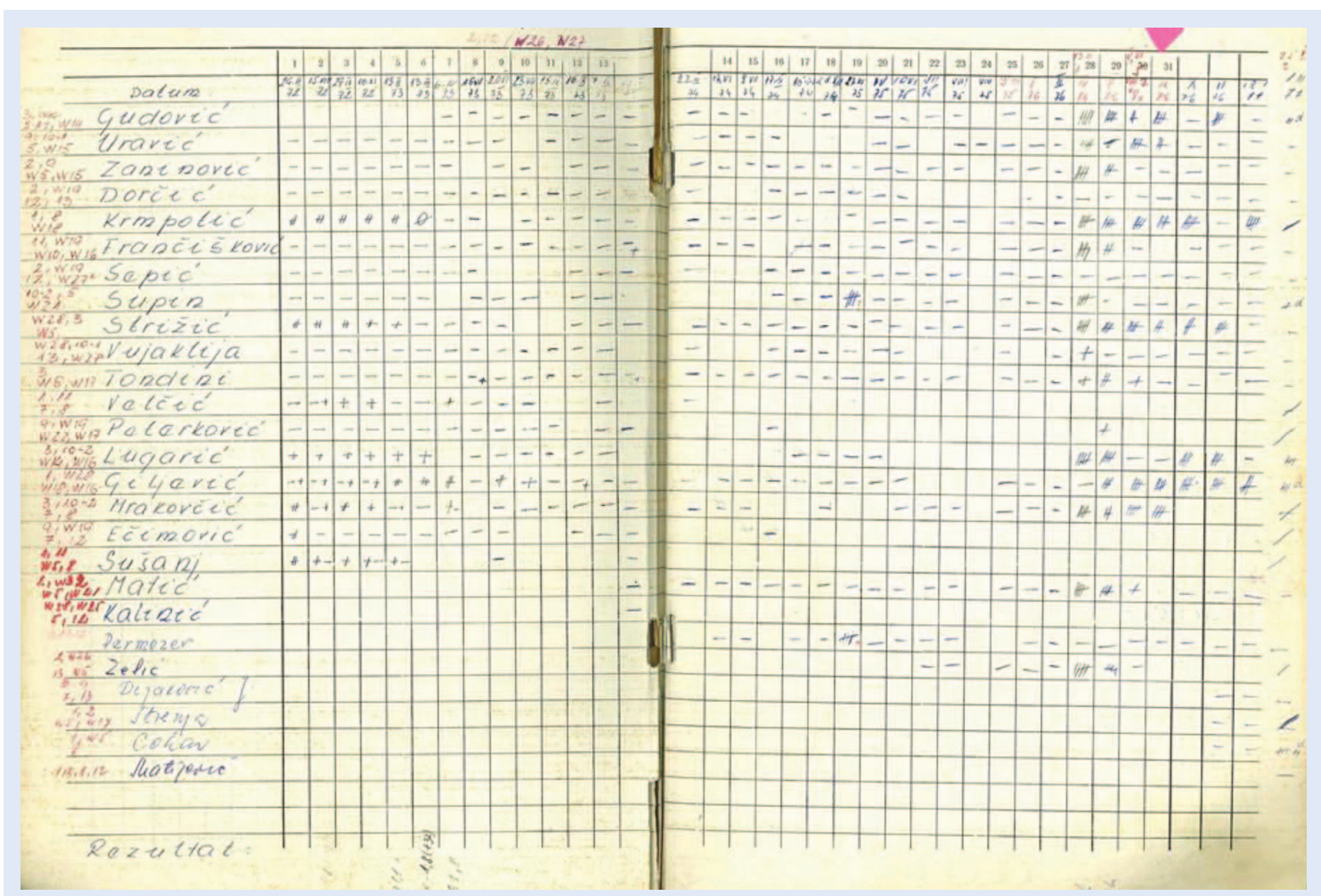

Slika 6. Rezultati prvog screeninga u Laboratoriju za tipizaciju tkiva u Rijeci (početak 1972.) 
KRIŽNA PROBA IZMEĐU LIMFOCITA DAVATELJA I SERUMA PRIMATELJA

Prije transplantacije bubrega izvodi se križna proba (engl. Crossmatch; CM) između limfocita davatelja i seruma primatelja kako bi se dokazalo eventualno prisustvo donor-specifičnih protutijela. U Laboratoriju za tipizaciju tkiva križna proba prije transplantacije bubrega izvodila se metodom CDC već od prvih zahvata. Ova metoda ostala je do današnjih dana zlatnim standardom prijetransplantacijskog ispitivanja podudarnosti između primatelja i davatelja bubrega. Naime, pozitivna križna proba sa „svježim“ uzorkom seruma, uzetim prije transplantacije, predstavlja apsolutnu kontraindikaciju za zahvat.

$\mathrm{U}$ početku se CM prije transplantacije radio u neimuniziranih primatelja s posljednjim uzorkom seruma, a u imuniziranih sa što većim brojem raspoloživih seruma ${ }^{8}$. Slijedeći nove spoznaje, uvodile su se modifikacije standardnog načina izvođenja testa kako bi se povećala osjetljivost metode poput produžene inkubacije, odvajanja limfocita T i B, izvođenje testa na različitim temperaturama. Kako rezultati nisu upućivali na povećanu osjetljivost, te su metode zbog svoje složenosti postupno napuštane. Od 2008., usporedno s uvođenjem DTT reagensa u screening pacijenata metodom CDC-a, započelo je i izvođenje križne probe navedenom metodom s i bez DTT-a kako bi se razlučio razred (IgM, IgG) donor-specifičnih protutijela HLA.

Danas se test izvodi u neimuniziranih primatelja sa „svježim“ uzorkom seruma iz krvi izvađene unutar 48 sati prije transplantacije te s uzorkom seruma koji je testiran tijekom posljednjeg screeninga. Crossmatch imuniziranih primatelja, uz navedene, izvodi se i s uzorcima seruma u kojima je dokazan najviši titar protutijela HLA.

Praćenje suvremenih spoznaja u području transplantacijske imunologije omogućilo je donošenje odluke transplantacijskog tima KBC-a Rijeka 12. veljače 2014. o usvajanju transplantacijskog protokola kojim se kirurškom zahvatu transplantacije bubrega pristupa bez čekanja na rezultate crossmatcha $u$ neimuniziranih pacijenata ${ }^{12}$. Time se značajno skraćuje vrijeme hladne ishemije kao jednog od čimbenika rizika koji imaju značajan utjecaj na ishod presađivanja bubrega ${ }^{23}$.
U poboljšanju ishoda transplantacija sa živih davatelja koje su bile učestale u početku transplantacijskog programa presađivanja bubrega u Rijeci značajno je bilo uvođenje testa za određivanje aloreaktivnosti limfocita miješanih u kulturi (engl. Mixed lymphocyte culture; MLC). Test je uveden u Centru za tipizaciju tkiva KBC-a Zagreb (voditelj prof. dr. sc. Andrija Kaštelan) 1976., a nakon četiri godine, od 1980., u Zavodu za fiziologiju i imunologiju Medicinskog fakulteta u Rijeci u suradnji s akademikom Danielom Rukavinom ${ }^{3}$. Test miješane kulture limfocita bio je sve do početka 1997. dijelom testiranja pacijenata i živog potencijalnog davatelja prije i/ili nakon transplantacije bubrega. Transplantacija bubrega predstavlja terapiju izbora za pacijente s kroničnim bubrežnim zatajenjem. Rijeka se vrlo brzo razvila u vodeći transplantacijski centar Jugoslavije, a danas je riječki KBC Referentni centar za transplantaciju bubrega Ministarstva zdravstva i jedna od ustanova s najrazvijenijim darivateljskim programom u Hrvatskoj24. Laboratorij za tipizaciju tkiva od svog je osnutka nezaobilazni sudionik u razvoju kliničke transplantacije u Rijeci. Jedan je od dva hrvatska i više od 200 laboratorija koji su ostvarili akreditaciju najvećeg europskog udruženja imunogenetičara (EFI). Usvajanje novih saznanja transplantacijske imunologije i imunogenetike, razvoj i primjena novih tehnologija i meto$\mathrm{da}$, suradnja s Eurotransplantom, sudjelovanje u međunarodnim, multicentričnim studijama uz veliki entuzijazam djelatnika čvrsto su utkali rad Laboratorija za tipizaciju tkiva u Rijeci u najsjajniju epohu riječke medicine.

\section{ZAHVALA}

Autori zahvaljuju svim djelatnicima i suradnicima Laboratorija za tipizaciju tkiva koji su omogućili stvaranje temelja imunogenetike i pridonijeli razvoju transplantacijske imunologije u Rijeci.

Izjava o sukobu interesa: Autorice izjavljuju da ne postoji sukob interesa.

\section{LITERATURA}

1. Nacionalni transplantacijski program [Internet]. Ministarstvo zdravstva Republike Hrvatske; c2018 [cited 2018 Dec 10]. Available from: https://zdravlje.gov.hr/nacionalni-transplantacijski-program/1528

2. Frančišković V, Vlahović Š, Zec J, Orlić P, Peterković V. Transplantacija bubrega - prikaz jednog slučaja. Liječ 
Vjesn 1971;93:849-573. Vujaklija-Stipanović K. Transplantacija bubrega: dodatni impuls riječkoj medicini. Act Facult Med Flum 1994;19:79-82.

4. Balen $\mathrm{S}$, Katalinić $\mathrm{N}$. Značaj sustava HLA u transplantaciji bubrega i osvrt na povijesni razvoj tipizacije tkiva u Rijeci. In: Rukavina D, Rački S (eds). Transplantacija bubrega u Rijeci. Povijesni osvrt i sadašnje stanje. Proceedings of the 7th Scientific Symposium; 2015 April 9; Rijeka, Croatia. Zagreb-Rijeka: HAZU, 2016;59-76.

5. Opelz G, Döhler B, Ruhenstroth A, Cinca S, Unterrainer $C$, Stricker $L$ et al. The collaborative transplant study registry. Transplant Rev (Orlando) 2013;27:43-5.

6. Introduction [Internet]. Collaborative Transplant Study; c1998-2018 [cited 2017 April 16]. Available from: http:// www.ctstransplant.org/public/introduction.shtml

7. O Eurotransplantu [Internet]. Eurotransplant; c2018 [cited 2018 Dec 10]. Available from: https://www.eurotransplant.org/cms/index.php?page=pat_croatia

8. Frančišković $V$, Čohar F, Gudović $A$, Orlić $P$, Smokvina $D$, Strižić $V$ et al. Iskustva nakon 40 transplantacija bubrega. Liječ Vjesn 1975;97:323-31.

9. Orlić P. Pretranplantacijski status i procjena intenziteta imunosupresije i predviđanja krize odbacivanja. Rijeka: Medicinski fakultet, 1985. PhD thesis.

10. Lim WH, Chadban SJ, Clayton P, Budgeon CA, Murray K, Campbell SB et al. Human leukocyte antigen mismatches associated with increased risk of rejection, graft failure, and death independent of initial immunosuppression in renal transplant recipients. Clin Transplant 2012;26: E428-37.

11. Opelz G, Döhler B. Effect of human leukocyte antigen compatibility on kidney graft survival: comparative analysis of two decades. Transplantation 2007;84:137-43.

12. Katalinić N. Uloga povijesnog razvoja u upravljanju metodama tipizacije tkiva u transplantaciji bubrega u Rijeci. Osijek: Medicinski fakultet, 2018. PhD thesis.

13. Kaštelan A. Rad Sekcije za imunologiju. Knjiga izvještaja I. kongresa i 3. skupštine „Jugotransplanta“; Opatija 1978. Rijeka: Tipograf-Rijeka, 1980:21-4.

14. Povijest transplantacije u Hrvatskoj [Internet]. Hrvatska donorska mreža; c2016 [cited 2018 Dec 15]. Available from: http://www.hdm.hr/2003/06/17/povijest-transplantacijeu-hrvatskoj/

15. Lobashevsky AL. Methodological aspects of anti-human leukocyte antigen antibody analysis in solid organ transplantation. World J Transplant 2014;4:153-67.

16. Terasaki PI, Kreisler M, Mickey RM. Presensitization and kidney transplant failures. Postgrad Med J 1971;47:89100.

17. Terasaki PI, Cai J. Humoral theory of transplantation: Further evidence. Curr Opin Immunol 2005;17:541-5.

18. Tait BD, Hudson F, Cantwell L, Brewin G, Holdsworth R, Bennett $G$ et al. Review article: Luminex technology for HLA antibody detection in organ transplantation. Nephrology (Carlton) 2009;14:247-54.

19. O'Rourke RW, Osorio RW, Freise CE, Lou CD, Garovoy $M R$, Bacchetti $P$ et al. Flow cytometry crossmatching as a predictor of acute rejection in sensitized recipients of cadaveric renal transplants. Clin Transplant 2000;14: 167-73.

20. Buelow R, Chiang TR, Monteiro F, Cornejo MC, Ellingson $L$, Claas $F$ et al. Soluble HLA antigens and ELISA-a new technology for crossmatch testing. Transplantation 1995;60:1594-9.

21. Colombo MB, Haworth SE, Poli F, Nocco A, Puglisi G, Innocente $A$ et al. Luminex technology for anti-HLA antibody screening: evaluation of performance and of impact on laboratory routine. Cytometry B Clin Cytom 2007;72:465-71.

22. Vujaklija-Stipanović K. Transfuzija krvi u transplantaciji bubrega. Rijeka: Medicinski fakultet, 1989. PhD thesis.

23. Rački $S$, Bašić-Jukić $N$, Kes $P$, Sabljar-Matovinović $M$, Ratković-Gusić I, Bušić $\mathrm{M}$ et al. Nacionalne smjernice za obradu i odabir primatelja i darivatelja bubrega usklađene sa smjernicama 2013. ERBP GUIDELINE ON THE MANAGEMENT AND EVALUATION OF THE KIDNEY DONOR AND RECIPIENT 2nd Edition. Zagreb: Ministarstvo zdravlja Republike Hrvatske, 2016; 31-6.

24. Fučkar Ž, Markić D, Španjol J, Valenčić M. Povijest transplantacije bubrega u bolnici na Sušaku. Acta Med Croatica 2011;65:323-9. 